\title{
Are we aiming to miss in translational autoimmunity
}

\section{treatments? [version 1; peer review: 3 approved, 1 approved with reservations]}

\author{
Gisela M. Vaitaitis (D)1,2, David H. Wagner ${ }^{1,2}$ \\ ${ }^{1}$ Webb-Waring Center, University of Colorado, Anschutz Medical Campus, Aurora, CO, 80045, USA \\ ${ }^{2}$ Department of Medicine, University of Colorado, Anschutz Medical Campus, Aurora, CO, 80045, USA
}

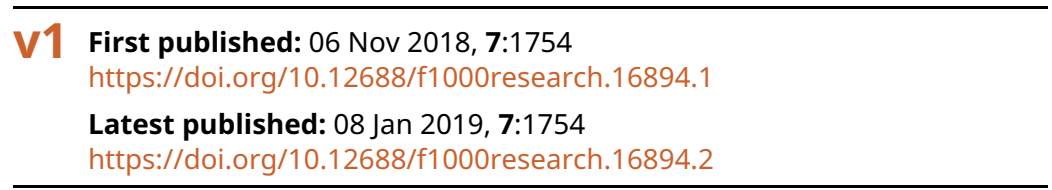

\section{Abstract}

Autoimmunity treatments, fruitfully pioneered in mouse models, can be disappointing or result in immunosuppression and opportunistic infections in translational trials. Many possible reasons exist, but one major, overlooked reason may be the treatment timing in relation to circadian oscillations of the immune system. Mice and humans both have immunological circadian clocks and experience the same circulatory oscillations of immune cells with regards to their sleep/wake phases, but have opposite sleep/wake phases with regard to the daylight cycle. Therefore, researchers mainly study mice and potential autoimmunity treatments during the murine sleep/rest phase, which is when pro-inflammatory mediators and more adaptive immune cells are prevalent in the circulation. In translational trials, however, treatment administration happens primarily during a patient's wake/activity phase, during the daytime, which is when more local and acute immune responses are active in the circulation. Therefore, we believe that the most opportune window for autoimmunity treatment may be missed in translational trials. Shifting the timing, and adjusting dosing to target only immune cells that are active at that time, may result in higher success with minimized immunosuppression or toxicities.

\section{Keywords}

autoimmunity, treatment, translational, circadian, timing, dosing

\section{Open Peer Review}

$\begin{array}{rccc}\text { Approval Status } & ? \\ 1 & 2 & 3 & 4\end{array}$

\section{version 2}

(revision)

08 Jan 2019

version 1

06 Nov 2018
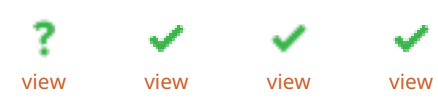

1. Chris Kevil, Louisiana State University Health Shreveport, Shreveport, USA

2. Li Wen, Yale School of Medicine, New Haven, USA

3. Hubert M. Tse ID, University of Alabama at Birmingham, Birmingham, USA

4. Jon Piganelli ID, University of Pittsburgh School of Medicine, Pittsburgh, USA Any reports and responses or comments on the article can be found at the end of the article. 
Corresponding author: David H. Wagner (david.wagner@ucdenver.edu)

Author roles: Vaitaitis GM: Conceptualization, Investigation, Project Administration, Visualization, Writing - Original Draft Preparation; Wagner DH: Resources, Supervision, Writing - Review \& Editing

Competing interests: No competing interests were disclosed.

Grant information: The author(s) declared that no grants were involved in supporting this work.

Copyright: ( 2018 Vaitaitis GM and Wagner DH. This is an open access article distributed under the terms of the Creative Commons Attribution License, which permits unrestricted use, distribution, and reproduction in any medium, provided the original work is properly cited.

How to cite this article: Vaitaitis GM and Wagner DH. Are we aiming to miss in translational autoimmunity treatments? [version 1; peer review: 3 approved, 1 approved with reservations] F1000Research 2018, 7:1754 https://doi.org/10.12688/f1000research.16894.1

First published: 06 Nov 2018, 7:1754 https://doi.org/10.12688/f1000research.16894.1 


\section{Translational treatments of autoimmunity often do not reflect findings in mouse models}

Mouse models of autoimmunity are widely used and, while they are not perfect, they are often the best available tools for research in potential treatments for a number of human autoimmune diseases such as type 1 diabetes, rheumatoid arthritis, and multiple sclerosis (MS), to name but a few. In such mouse models, many potential therapeutics demonstrate great effects in preventing the development of disease, ameliorating the disease symptoms, or even curing the fulminant autoimmunity ${ }^{1-5}$. However, when applying therapeutics in translational medicine, clinical trials often are disappointing, demonstrating low or short-lived efficacy ${ }^{6-8}$. Many therapeutics come with toxicities that, in some cases, can be mitigated. However, once toxicities are addressed, the efficacy often remains at a point of ameliorating symptoms to some degree, but not in all patients, and rarely do the therapeutics cure the patients ${ }^{6,9}$. There are successful treatments that ameliorate human autoimmune disease; however, those treatments can be broadly immune suppressive, causing opportunistic infections in the patient ${ }^{10,11}$.

Differences in success of autoimmunity treatments in mice compared to humans could certainly be due to that autoimmunity in humans is different from the mouse models. The mouse models likely address only some of the possible etiologies of human autoimmune disease when the human disease consists of many different facets and etiologies, genetics, environmental differences, relative exposures etc., that converge on the same types of symptoms. Therefore, those etiologies are not all treatable with one strategy that may have been elucidated in the mouse model. However, when directing the autoimmunity therapy at events upon which all the etiologies may converge, such as killing or tolerizing $\mathrm{T}$ cells that are attacking self-tissues, why do therapies not have better outcomes? Could timing be at the core?

In this opinion paper, we wish to highlight one major overlooked possibility for some of the discrepancies between the findings in mouse and human autoimmunity treatments. We are by no means dismissing other possibilities since there are likely many reasons for the discrepancies; however, we feel that the particular possibility presented in this piece has yet to be considered.

\section{Circadian rhythm of the immune system and autoimmunity treatments}

In 2017, the Nobel Prize in Physiology or Medicine was awarded for work on understanding circadian rhythm ${ }^{12}$. That work has led to the understanding that not only is there a "master clock" that governs the biorhythm of humans and animals alike, but there are many organ specific "clocks" that turn individual organ processes on and off, perhaps several times in a 24 hour period. This turns out to be true for the immune system as well $^{13}$. Interestingly, there are different circadian rhythms for different parts of the immune system. Basal plasma levels of pro-inflammatory cytokines such as IL-1 $\beta, \mathrm{TNF} \alpha$, IFN $\gamma$, and IL-6 are higher during the sleep/rest phase and are paralleled by an abundance of memory and naïve $\mathrm{T}$ cells in the circulation ${ }^{13}$. Contrarily, anti-inflammatory cytokines, such as IL-4 and IL-10, increase upon awakening and $\mathrm{CD}^{+}$effector $\mathrm{T}$ cells as well as natural killer $\mathrm{T}$ cells peak during the wake/active phase ${ }^{13}$. This results in more local cytotoxic activities during the active phase, when it is also more likely that wounding and acute pathogen and antigen exposure will occur ${ }^{13}$.

The diurnal oscillation in $\mathrm{T}$ and $\mathrm{B}$ cells in the circulation is paralleled by an opposite oscillation phase in the lymph nodes ${ }^{14,15}$. These oscillations have implications in different disease courses as well as for vaccinations. For example, the disease course in the experimental autoimmune encephalomyelitis (EAE) mouse model of MS is significantly more severe if the disease induction regimen is given during the light cycle (when mice sleep/rest) than if given during the dark cycle (when mice are awake/active) ${ }^{14}$. Similarly, the magnitude of Leishmania infection is dependent on the circadian time of infection ${ }^{16}$. In humans, the timing of vaccination has been demonstrated to have an impact on the efficacy of the vaccine, where giving the influenza vaccine to patients in the morning enhanced the antibody response compared to when giving it in the afternoon ${ }^{17}$. On the flip-side of this, severe disturbances in the sleep/wake cycle, such as during shift work, has been shown to cause significant health problems, including increased association with autoimmune disease ${ }^{18}$. Given the circadian oscillations of the immune system and the impact of those oscillations on infection and vaccination/ disease induction, it is not farfetched to consider that the efficacy of immune system targeting treatments would also be affected by the timing of treatment administration in relation to such oscillations.

Humans and mice have an opposite sleep/rest and wake/activity schedule in regards to the daylight cycle, but have the same oscillations in the innate and adaptive immune system in regards to the sleep/rest and wake/activity phases ${ }^{13}$. Researchers tend to study mice primarily during the murine sleep/rest cycle, as that happens when the researcher is awake. Therefore, test treatments in mice affect immunological processes that are prevalent during the sleep/rest cycle, i.e. pro-inflammatory activities and memory cell formation ${ }^{13}$. When translating the findings to humans, however, the opposite occurs. Human subjects are treated primarily during the wake/activity cycle, again for convenience. Therefore, patients are treated when antiinflammatory mediators and local cytotoxic immune responses are active in the circulation but not when adaptive responses are prevalent. Since pro-inflammatory activities drive autoimmunity, and that type of activity occurs in the circulation mostly during the sleep/rest phase, the best window for treatment in humans may very well be missed (Figure 1). Depending on the stability of a therapeutic, much of it may have been degraded or metabolized by the time the actual intended target is present in the circulation. In the case of therapeutic antibodies, which are generally considered to have good stability, the antibodies may be engulfed through endocytosis or pinocytosis ${ }^{19}$ by cells other than the target cells and therefore become less available by the time the target cells are present. In addition, depending on what the particular therapeutic target molecule is, cells other than the intended ones, which also express that particular molecule and are present in the circulation during the wake/ 

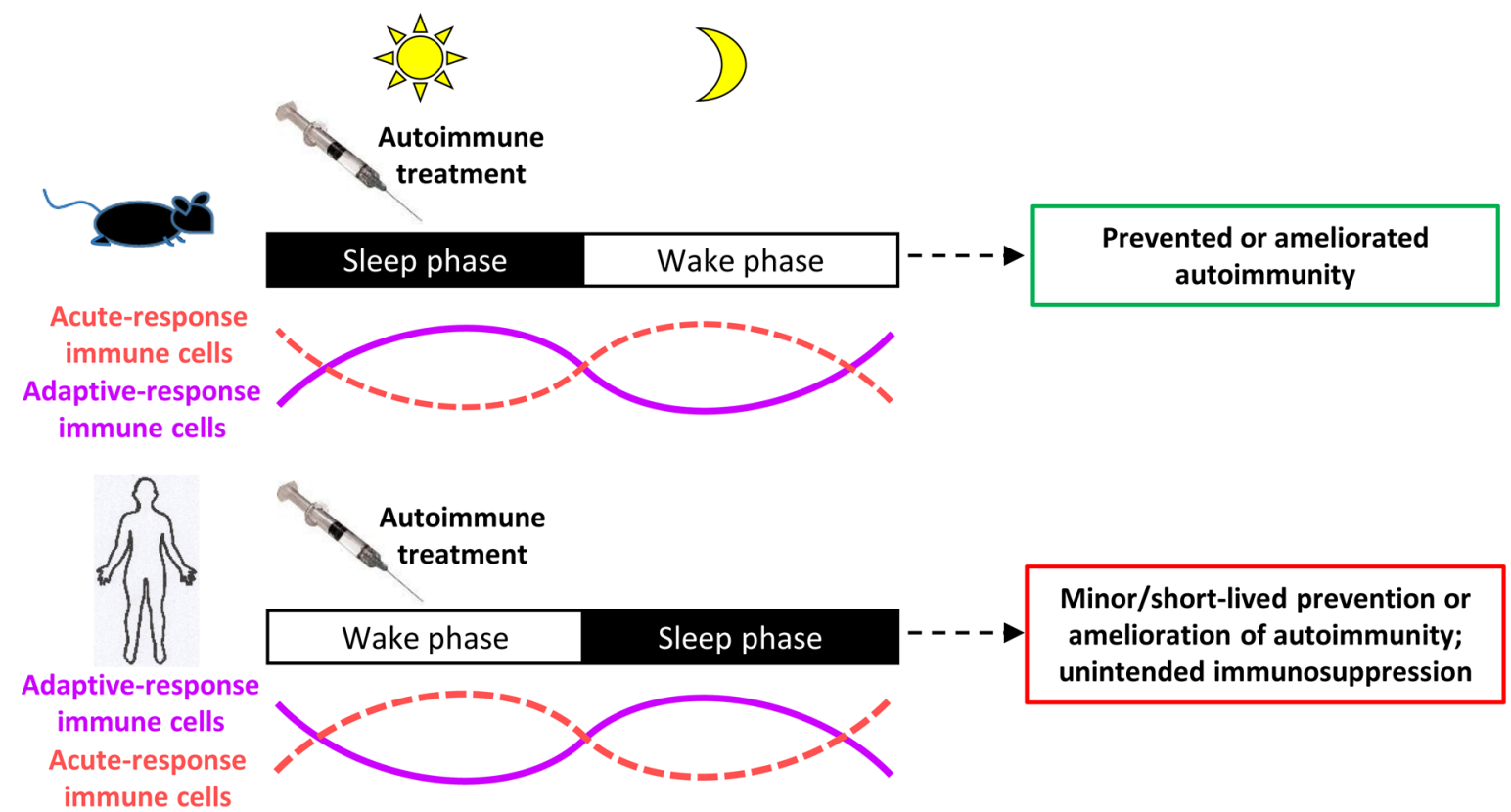

Figure 1. Autoimmunity treatments are applied at opposite immune system peaks in mice compared to humans. Humans and mice have different wake/activity and sleep/rest phases with regard to the daylight cycle. Because of this, researchers perform autoimmunity treatments at very different immune system peak times in humans compared to mice, which may account for some disappointing treatment trial outcomes in human autoimmunity.

activity phase, may be targeted thus causing a broader immune suppression than intended.

\section{Timing and dosing in relation to toxicities and success of autoimmunity treatments}

Recently it has become more apparent that there is a biologically and medically relevant impact of time-of-day in administering pharmaceuticals or in encountering environmental toxicants, where the time-of-day significantly modulates the efficacy and toxicity of the administered drug or encountered toxicant ${ }^{20}$. The timing and dose of therapeutics administration in autoimmunity may also be tied to toxicities or immunosuppression. Often the thinking is that if a therapeutic with a reasonably long halflife is given in a high (but tolerated) dose then there will be a maximum effect for the patient. However, it is possible that by doing so, the therapeutic ends up targeting a much broader range of immune cells that may share expression of the same target molecule as the intended target cells, causing unnecessary immune suppression. For example, if a large dose of a $\mathrm{T}$ cell inhibitory antibody (targeting a molecule expressed on most $\mathrm{T}$ cells) is given during the wake/activity phase, it will first target CD8 effector and natural killer $\mathrm{T}$ cells since they are present in the circulation at that time. Subsequently, it will target the intended memory and naïve $\mathrm{T}$ cells once the sleep/rest phase is entered. This could happen several times over several days or weeks until the antibody is no longer available and may unnecessarily render the patient unable to respond to acute pathogen exposure. If the antibody instead is given in a smaller dose during the sleep/rest phase, it may adequately target the intended cells (memory and naïve $\mathrm{T}$ cells) but not be available to target other cells (CD8 effector and natural killer $\mathrm{T}$ cells) once the wake/ activity phase is entered, thereby allowing for adequate acute pathogen response.

In the case of attempts to tolerize autoreactive $\mathrm{T}$ cells to selfantigens $^{21-24}$, a similar scenario may be at play. Restoring tolerance with small doses of antigen works well in the setting of $\operatorname{IgE}$ driven allergy ${ }^{25,26}$. However, in autoimmunity there has thus far been very limited success ${ }^{8}$. One hypothesis could be that, in allergies, the target cells/molecules that initiate the allergic response are those that are active during the wake/activity phase, which is also the period that human subjects normally encounter allergens. Therefore, administering a small dose of antigen during the wake/activity phase works to target the intended immune cells and is then, because of the low dose, no longer available by the time the sleep/rest phase commences. In autoimmunity, however, the intended target cells, B cells, CD4 helper $\mathrm{T}$ cells, etc. are more prominent during the sleep/rest phase. Therefore, administering the antigen to humans during the daytime may target the wrong cells and the small dose of antigen will be more or less exhausted by the entry into sleep/rest phase, resulting in inadequate targeting of the intended cells.

\section{Concluding remarks}

Obviously, the circadian rhythm of the immune system may not be at play in the efficacy of all autoimmunity treatments. However, considering the oscillations of immune cells in the circulation in some autoimmunity therapies may be prudent. 
Determining when the target molecules/immune cells are present in the circulation and administering small doses of the therapeutic at that point may maximize the effect and lessen unintended consequences. Currently, researchers are serendipitously targeting the culprit cells/molecules in autoimmune mouse model studies because of the difference in mice's sleep/wake phases and ours. While it may be difficult to treat human autoimmunity during the sleep/rest phase, it may pay off with an increase in the therapeutic effect. To address this question, experiments can be done on autoimmune mice housed in an altered light cycle such that their sleep/wake cycle coincides with ours and therefore treatments can easily be applied when anti-inflammatory mediators and local cytotoxic immune responses are active in their circulation. Thus it can be ascertained whether the efficacy of the treatments lessen when applied during the wake/activity phase. While it may be more difficult to accomplish, in human trials of autoimmunity treatments it would be useful to assign some subjects to groups receiving treatment at different times during a 24-hour period, especially during the sleep/rest phase. Certainly, it would be worthwhile to revisit treatments that previously demonstrated great efficacy in mouse models but only slight improvements in translational treatments.

\section{Data availability}

No data are associated with this article.

\section{Grant information}

The author(s) declared that no grants were involved in supporting this work.
1. Xiao X, Guo P, Shiota C, et al.: Endogenous Reprogramming of Alpha Cells into Beta Cells, Induced by Viral Gene Therapy, Reverses Autoimmune Diabetes. Cell Stem Cell. 2018; 22(1): 78-90.e4.

PubMed Abstract | Publisher Full Text | Free Full Text

2. Vaitaitis GM, Olmstead MH, Waid DM, et al:: A CD40-targeted peptide controls and reverses type 1 diabetes in NOD mice. Diabetologia. 2014; 57(11): 2366-73. PubMed Abstract | Publisher Full Text | Free Full Text

3. Benedek G, Chaudhary P, Meza-Romero R, et al:: Sex-dependent treatment of chronic EAE with partial MHC class II constructs. J Neuroinflammation. 2017; 14(1): 100.

PubMed Abstract | Publisher Full Text | Free Full Text

4. Elliott DM, Singh N, Nagarkatti M, et al:: Cannabidiol Attenuates Experimental Autoimmune Encephalomyelitis Model of Multiple Sclerosis Through Induction of Myeloid-Derived Suppressor Cells. Front Immunol. 2018; 9: 1782. PubMed Abstract | Publisher Full Text | Free Full Text

5. Zhang Q, Dehaini D, Zhang Y, et al:: Neutrophil membrane-coated nanoparticles inhibit synovial inflammation and alleviate joint damage in inflammatory arthritis. Nat Nanotechnol. 2018. PubMed Abstract | Publisher Full Text

6. Rosenblum MD, Gratz IK, Paw JS, et al.: Treating human autoimmunity: current practice and future prospects. Sci Transl Med. 2012; 4(125): $125 \mathrm{sr} 1$. PubMed Abstract | Publisher Full Text | Free Full Text

7. Creusot RJ, Postigo-Fernandez J, Teteloshvili N: Altered Function of AntigenPresenting Cells in Type 1 Diabetes: A Challenge for Antigen-Specific Immunotherapy? Diabetes. 2018; 67(8): 1481-94. PubMed Abstract | Publisher Full Text | Free Full Text

8. Bleich D, Wagner DH: Challenges to Reshape the Future of Type 1 Diabetes Research. J Clin Endocrinol Metab. 2018; 103(8): 2838-2842. PubMed Abstract | Publisher Full Text

9. Li $P$, Zheng $Y$, Chen $X$ : Drugs for Autoimmune Inflammatory Diseases: From Small Molecule Compounds to Anti-TNF Biologics. Front Pharmacol. 2017; 8: 460. PubMed Abstract | Publisher Full Text | Free Full Text

10. Prior DE, Nurre E, Roller SL, et al:: Infections and the relationship to treatment in neuromuscular autoimmunity. Muscle Nerve. 2018; 57(6): 927-31. PubMed Abstract | Publisher Full Text | Free Full Text

11. Tudesq JJ, Cartron G, Rivière $S$, et al:: Clinical and microbiologica characteristics of the infections in patients treated with rituximab for autoimmune and/or malignant hematological disorders. Autoimmun Rev. 2018; 17(2): 115-24.

PubMed Abstract | Publisher Full Text

12. Sehgal A: Physiology Flies with Time. Cell. 2017; 171(6): 1232-5. PubMed Abstract | Publisher Full Text

13. Geiger SS, Fagundes CT, Siegel RM: Chrono-immunology: progress and challenges in understanding links between the circadian and immune systems. Immunology. 2015; 146(3): 349-58.

PubMed Abstract | Publisher Full Text | Free Full Text

14. Druzd D, Matveeva O, Ince L, et al:: Lymphocyte Circadian Clocks Control
Lymph Node Trafficking and Adaptive Immune Responses. Immunity. 2017; 46(1): 120-32.

PubMed Abstract | Publisher Full Text | Free Full Text

15. Suzuki K, Hayano Y, Nakai A, et al.: Adrenergic control of the adaptive immune response by diurnal lymphocyte recirculation through lymph nodes. J Exp Med. 2016; 213(12): 2567-74

PubMed Abstract | Publisher Full Text | Free Full Text

16. Kiessling S, Dubeau-Laramée G, Ohm H, et al:: The circadian clock in immune cells controls the magnitude of Leishmania parasite infection. Sci Rep. 2017; 7(1): 10892

PubMed Abstract | Publisher Full Text | Free Full Text

17. Long JE, Drayson MT, Taylor AE, et al:: Morning vaccination enhances antibody response over afternoon vaccination: A cluster-randomised trial. Vaccine. 2016; 34(24): 2679-85.

PubMed Abstract | Publisher Full Text | Free Full Text

18. Toth LA, Trammell RA, Liberati T, et al:: Influence of Chronic Exposure to Simulated Shift Work on Disease and Longevity in Disease-Prone Inbred Mice. Comp Med. 2017; 67(2): 116-26.

PubMed Abstract | Free Full Text

19. Keizer RJ, Huitema AD, Schellens JH, et al:: Clinical pharmacokinetics of therapeutic monoclonal antibodies. Clin Pharmacokinet. 2010; 49(8): 493-507. PubMed Abstract | Publisher Full Text

20. Dallmann R, Okyar A, Lévi F: Dosing-Time Makes the Poison: Circadian Regulation and Pharmacotherapy. Trends Mol Med. 2016; 22(5): 430-45. PubMed Abstract | Publisher Full Text

21. Ludvigsson J, Krisky D, Casas R, et al:: GAD65 antigen therapy in recently diagnosed type 1 diabetes mellitus. N Engl J Med. 2012; 366(5): 433-42. PubMed Abstract | Publisher Full Text

22. Diabetes Prevention Trial--Type 1 Diabetes Study Group: Effects of insulin in relatives of patients with type 1 diabetes mellitus. N Engl J Med. 2002; 346(22): 1685-91.

PubMed Abstract | Publisher Full Text

23. Skyler JS, Krischer JP, Wolfsdorf J, et al:: Effects of oral insulin in relatives of patients with type 1 diabetes: The Diabetes Prevention Trial--Type 1. Diabetes care. 2005; 28(5): 1068-76.

PubMed Abstract | Publisher Full Text

24. Writing Committee for the Type 1 Diabetes TrialNet Oral Insulin Study Group, Krischer JP, Schatz DA, et al.: Effect of Oral Insulin on Prevention of Diabetes in Relatives of Patients With Type 1 Diabetes: A Randomized Clinical Trial. JAMA. 2017; 318(19): 1891-902.

PubMed Abstract | Publisher Full Text | Free Full Text

25. Matsuoka T, Shamji MH, Durham SR: Allergen immunotherapy and tolerance. Allergol Int. 2013; 62(4): 403-13.

PublMed Abstract | Publisher Full Text

26. Arasi $\mathrm{S}$, Corsello $\mathrm{G}$, Villani $\mathrm{A}$, et al:: The future outlook on allergen immunotherapy in children: 2018 and beyond. Ital J Pediatr. 2018; 44(1): 80. PubMed Abstract | Publisher Full Text | Free Full Text 


\section{Open Peer Review}

\section{Current Peer Review Status:}

Version 1

Reviewer Report 07 December 2018

https://doi.org/10.5256/f1000research.18471.r40304

(C) 2018 Piganelli J. This is an open access peer review report distributed under the terms of the Creative Commons Attribution License, which permits unrestricted use, distribution, and reproduction in any medium, provided the original work is properly cited.

\section{Jon Piganelli}

Department of Surgery, University of Pittsburgh School of Medicine, Pittsburgh, PA, USA

Vaitaitis and Wagner present an interesting hypothesis regarding the inability of effective immunotherapies for autoimmunity in mice to translate to human clinic. They describe the difference in sleep/wake cycle as a confounding factor in the translation. Where in mice, the majority of work is conducted during the rodent sleep cycle where as the authors state there is an increase in adaptive immune cells, those which are often targeted by these types of therapies. However these same treatments are given in the daylight/wake period of humans, where the adaptive immune system is less active. They propose to give these types of treatment during the sleep cycle in humans to facilitate the optimal targeting of the adaptive immune response to down-modulate the ensuing self-reactive response.

Although this makes sense there are a few caveats that must also be considered. For example, the administration route and dose may have a profound impact on the overall immune response. Also for dosing and and timing we assume that tissue distribution is limited if at all, and that the agent is not getting to the target tissue. This is likely not the case, as then many agents would fail to have any real therapeutic value at all. I understand the logic but as we know pharmacokinetics is extremely complex for drug delivery. Notwithstanding, the complexity of this is far greater still, since the interaction of the circulating immune cells, for example CD4-helper cells must interact with APC/DC in the draining lymph node, where the APC has ferried antigen where it can present to T cells, This interaction then puts the APC at the center of the issue and therefore the whereabouts of these cells at the time of antigen exposure becomes critical.

Overall, this article brings us out of the dark and into the light for just how much we take for granted in these types of experiments when moving to the clinic. Overall the author's suggestions to assess these differences warrant that these types of experiments are investigated. For example, the design of sustained delivery of agents that can be given in more conducive time frames that then release their payload during the sleep cycle may be impactful.

Is the topic of the opinion article discussed accurately in the context of the current literature? 
Yes

Are all factual statements correct and adequately supported by citations?

Yes

Are arguments sufficiently supported by evidence from the published literature?

Yes

Are the conclusions drawn balanced and justified on the basis of the presented arguments? Yes

Competing Interests: No competing interests were disclosed.

Reviewer Expertise: Autoimmunity, T cells, Redox-dependent signaling, immunometabolism

I confirm that I have read this submission and believe that I have an appropriate level of expertise to confirm that it is of an acceptable scientific standard.

\section{Author Response 07 Dec 2018}

Gisela Vaitaitis, University of Colorado, Anschutz Medical Campus, Aurora, USA

Dr. Piganelli,

Thank you very much for reviewing our manuscript. We greatly appreciate your time. Your comments and insights are well taken and we agree that there are many levels of complexity in autoimmunity treatments. We also agree that the explanation proposed in our manuscript for the discrepancy in success of autoimmunity treatments between mice and humans does not necessarily fit all situations. Nonetheless, adjusting the timing of administration of treatments may be very important for some therapeutics with resulting increase in success.

Competing Interests: None

Reviewer Report 22 November 2018

https://doi.org/10.5256/f1000research.18471.r40306

(c) 2018 Tse H. This is an open access peer review report distributed under the terms of the Creative Commons Attribution License, which permits unrestricted use, distribution, and reproduction in any medium, provided the original work is properly cited.

Hubert M. Tse

Comprehensive Diabetes Center, Department of Microbiology, School of Medicine, University of Alabama at Birmingham, Birmingham, AL, USA

Vaitaitis and Wagner have written an interesting opinion article regarding the shortcomings of 
mouse models of autoimmunity and their assessment of immunotherapies to delay disease progression in human clinical trials. Mouse models are instrumental in increasing our understanding of genetics and immune responses involved in disease pathogenesis. However, the identification of numerous interventions that can delay autoimmunity in mice are ineffective in humans. One potential scenario of the lack of success in translational studies may be due to opposite circadian clocks and sleep/wake phases in mice and humans. The authors provide an interesting opinion that is overlooked by immunologists and warrants attention in future studies. The opinion article is well written, but could be strengthened by providing examples of how some immunotherapies including anakinra and rituximab have shown to be efficacious in mice, but not in human clinical trials with respect to opposite circadian clocks.

Is the topic of the opinion article discussed accurately in the context of the current literature?

Yes

Are all factual statements correct and adequately supported by citations?

Yes

Are arguments sufficiently supported by evidence from the published literature? Partly

Are the conclusions drawn balanced and justified on the basis of the presented arguments? Yes

Competing Interests: No competing interests were disclosed.

I confirm that I have read this submission and believe that I have an appropriate level of expertise to confirm that it is of an acceptable scientific standard.

Author Response 24 Nov 2018

Gisela Vaitaitis, University of Colorado, Anschutz Medical Campus, Aurora, USA

Dr. Tse,

Thank you very much for reviewing our article. We are grateful for your time, input, and comments. We will take your comments into account when revising the manuscript to create version 2.

Competing Interests: None. 
(c) 2018 Wen L. This is an open access peer review report distributed under the terms of the Creative Commons Attribution License, which permits unrestricted use, distribution, and reproduction in any medium, provided the original work is properly cited.

\section{Li Wen}

Section of Endocrinology, Yale School of Medicine, New Haven, Connecticut, USA

Vaitaitis and Wagner published this timely opinion article regarding an obvious overlook of the circadian control of immune cells and the unsatisfactory outcome of clinical trials. The authors rightly pointed out that most, if not all, immune-therapies for human autoimmune diseases have been based on animal model, especially mouse model, studies. The mouse has a completely opposite circadian rhythm to humans. This could be one of the reasons that many clinical trials of immune therapy cannot be faithfully translated to humans. Pre-clinical studies, if not specific for circadian research, are all carried out in the daytime, when the mouse normally sleeps, whereas clinical studies in humans are conducted in the daytime, which is the human waking phase. In addition to the difference in circadian regulation of immune cell functions, importantly, the circadian regulation of metabolism of immune cells needs to be taken into consideration in the interpretation of the "failed" immunotherapies in humans, which have had positive outcomes in mouse model studies. The authors have made a very important point in highlighting this major overlooked possibility for some of the discrepancies in efficacy of treating autoimmune diseases, such as type 1 diabetes, between the mouse and human studies.

Is the topic of the opinion article discussed accurately in the context of the current literature?

Yes

Are all factual statements correct and adequately supported by citations? Yes

Are arguments sufficiently supported by evidence from the published literature? Yes

Are the conclusions drawn balanced and justified on the basis of the presented arguments? Yes

Competing Interests: No competing interests were disclosed.

I confirm that I have read this submission and believe that I have an appropriate level of expertise to confirm that it is of an acceptable scientific standard.

Author Response 20 Nov 2018

Gisela Vaitaitis, University of Colorado, Anschutz Medical Campus, Aurora, USA

Dr. Wen,

Thank you very much for taking the time to review our manuscript. We greatly appreciate 
your time, interest and comments.

Competing Interests: None

Reviewer Report 12 November 2018

https://doi.org/10.5256/f1000research.18471.r40307

(c) 2018 Kevil C. This is an open access peer review report distributed under the terms of the Creative Commons Attribution License, which permits unrestricted use, distribution, and reproduction in any medium, provided the original work is properly cited.

\section{Chris Kevil}

Department of Pathology, Louisiana State University Health Shreveport, Shreveport, LA, USA

This is an opinion article addressing the question whether missed opportunities have occurred due to inconsistent immune intervention studies between mice and men involving differential time of intervention. The proposed hypothesis is interesting and potentially plausible given the recent insights into circadian regulation of immune responses. However, the current opinion piece is not fully substantiated in certain areas requiring revision.

Are arguments adequately supported by evidence from the literature?

While the authors cite some reports highlighting circadian regulation of immunity, insufficient discussion was provided regarding specific differential immune responses and how they may actually impact tolerance strategies. Further discussion of this area would strengthen the work.

Is the topic of the opinion article discussed accurately in the context of the current literature?

Yes

Are all factual statements correct and adequately supported by citations? Yes

Are arguments sufficiently supported by evidence from the published literature? Partly

Are the conclusions drawn balanced and justified on the basis of the presented arguments? Yes

Competing Interests: No competing interests were disclosed.

I confirm that I have read this submission and believe that I have an appropriate level of expertise to confirm that it is of an acceptable scientific standard, however I have 


\section{significant reservations, as outlined above.}

\section{Author Response 16 Nov 2018}

Gisela Vaitaitis, University of Colorado, Anschutz Medical Campus, Aurora, USA

Dr. Kevil,

Thank you very much for taking the time to review our paper. We greatly appreciate your input and agree that we neglected to discuss the specific immune responses that are relevant in autoimmunity. We will update the manuscript to reflect this once we have the comments from other reviewers as well.

Competing Interests: None.

The benefits of publishing with F1000Research:

- Your article is published within days, with no editorial bias

- You can publish traditional articles, null/negative results, case reports, data notes and more

- The peer review process is transparent and collaborative

- Your article is indexed in PubMed after passing peer review

- Dedicated customer support at every stage

For pre-submission enquiries, contact research@f1000.com 